\title{
A Numerical Method for Solid Propellant Grain Design
}

\author{
Bojan Tanaskovski ${ }^{1)}$ \\ Jovica Nešić ${ }^{1)}$ \\ Ljiljana Jelisavac ${ }^{1)}$ \\ Jovica Bogdanov ${ }^{2)}$
}

\begin{abstract}
In this study, a grain burnback analysis for an Anchor solid propellant grain geometry for a rocket motor was done. The design process involves parametric modeling of the geometry in using PTC Creo software through dynamic variables that define the complex configuration.

Grain burnback is achieved by making new surfaces step by step and calculating geometrical properties at each web increment.

The surfaces of the grain are determined by PTC Creo 4.0 using grain shapes at every 5 mm thickness of the burned web. This procedure gives the sizes of the remaining grain surfaces, during its burning process in the Solid Rocket Motor. The results obtained using PTC Creo have been checked by the values of burning surfaces calculated using closed form of equations that describe the same geometry, in order to verify the correctness of numerical calculation.

The work presented deals with the application of the PTC Creo software tool for design of any arbitrary solid form of a rocket motor propellant grain. This work was concentrated on a numerical description and determination of the mathematical model of the burning process.
\end{abstract}

Key words: rocket motor, propellant, rocket propellant, solid rocket propellant, geometric shape, combustion, combustion surface, modeling, numerical methods.

\section{Introduction}

$\mathrm{D}^{1}$ IFFERENT complex shapes of solid rocket motor propellant grains may be required in accordance with thrust-time profiles depending on the rocket mission. The main parameter affecting the thrust-time profile is the grain geometry $[1,2,3]$.

Different types of thrust-time functions need the use of different shapes of propellant grains. When designing rocket motors, special significance is given to the design of the propellant grain [2-7].

According to the motor requirements, designer should choose the appropriate configuration [8]. Some recommendations for the choice of the propellant grain shapes can be found in references $[2,3,8]$.

As the propellant burns, the burning surface of the grain moves in a direction normal to the surface. This regression is called burnback. Grain burnback is achieved by making new surfaces at each web increment. It is a pure geometrical analysis of the burning surface distribution depending on the displacement of the flame front through the direction normally to the burning surface. This analysis aims to determine the changes in the grain geometry during the operation of the rocket motor [4]. At the end of the burnback analysis, on the basis of the obtained results the distribution of the "burning surface versus burnt layer thickness" can be made.

Analysis of solid propellant rocket motors is progressing in two levels, where, independent of the level, it is needed to assess the following two basic steps.

The steps are, at first, propellant grain configuration selection and defining the geometry which satisfies conditions of internal ballistics. In the second step, structural integrity analysis has to be done. This can be a process that is repeated several times, iteratively. For very complex profiles, especially for the structural analysis, the use of numerical models is required.

Nowadays, CAD software programs are used for modeling and drafting the grain geometry $[4,9,10,11,12,13]$.

In this paper PTC Creo 4.0 software was used for this purpose [14].

\section{Design and analysis of propellant grain}

The aim of this paper was to determine the change of the burning surface for the complex Anchor grain geometry using the PTC Creo software. The obtained results will be comparing with the results obtained by classical formulas in the closed form. These formulas were not available. Therefore, they derived on this occasion for the Anchor type of grain.

The task was to make burning surface distribution vs. burnt thickness, for the Anchor grain which outer diameter is equal to $(C)=280 \mathrm{~mm}$. The shape of the Anchor was used only as a sample for analyzing the possibilities of applying PTC Creo for this purpose. The Anchor geometry can be categorized as complex geometry [15].

The Anchor grain configuration is defined by seven independent variables. The Anchor grain configuration can be seen in Fig.1. The parameters which define the Anchor geometry are also given in Fig.1.

\footnotetext{
1) Military Technical Institute (VTI), Ratka Resanovića 1, 11132 Belgrade, SERBIA

2) University of Defence, Military Academy, Generala Pavla Jurišića Šturma 33, 11000 Belgrade, SERBIA

Correspondence to: Bojan Tanaskovski; e-mail: tanaskovskibojan@yahoo.com
} 

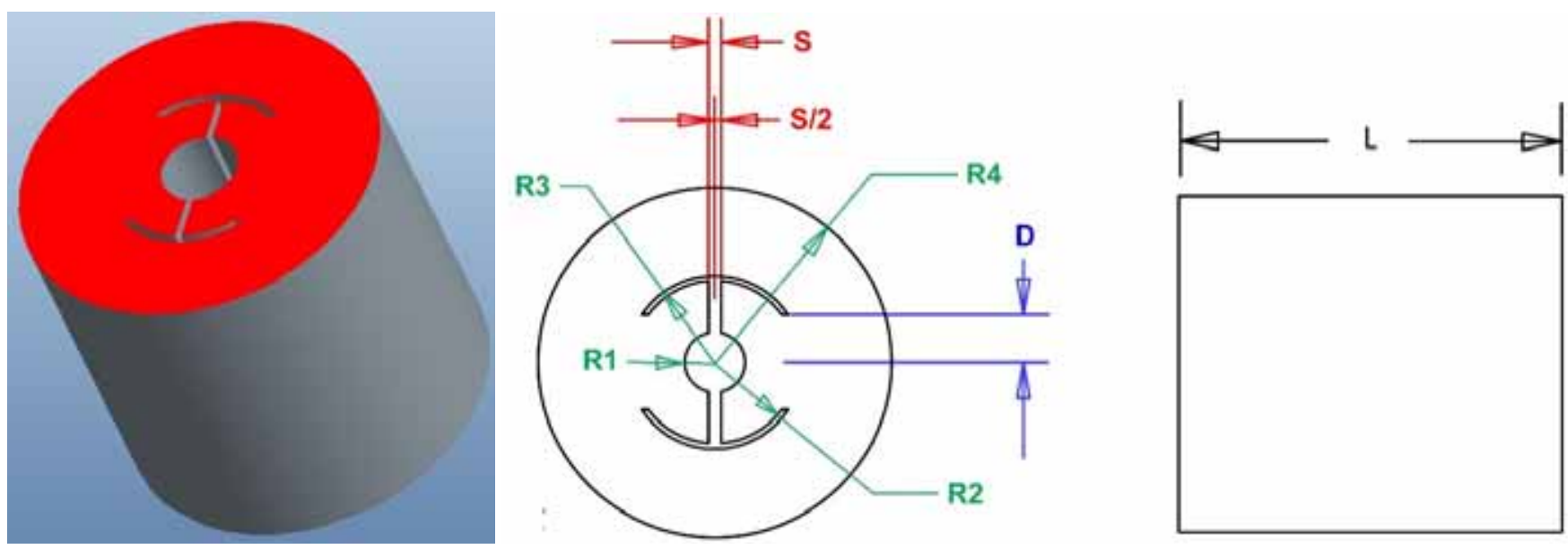

Figure 1. Anchor grain configuration with geometric parameters

The process of burning surface calculation involves parametric modeling of the geometry in PTC Creo software through dynamic variables that define the complex configuration.

The geometry was modeled parametrically and the parameters which change during the burnback process have been modifing for each burn step using PTC Creo program [16].

Grain burnback was achieved by making new surfaces at each web increment and calculating geometrical properties at each step. The procedure adopted can be applied to any complex geometry in a relatively simple way in the process of grain configuration design.

\section{Results and discussion}

The numerical results obtained by the program PTC Creo were compared with the results obtained by using the formulas that describe geometrically each combustion stages.

Table 1 gives the burning surface values in percentages, obtained by the program PTC Creo during the combustion, or after changing the burnt layer thickness or time of combustion.
Table 1. The burning surface values in relation to changing the burnt layer thickness for initial shape of grain

\begin{tabular}{||c|c|c|c|c|c|c||}
\hline \multicolumn{7}{|c|}{ I phase [0 B Burnt layer thickness $\leq 0,5(R 2-R 1)]$} \\
\hline \hline $\begin{array}{c}\text { Burnt layer thickness } \\
(\mathrm{mm})\end{array}$ & 0 & 5 & 10 & 15 & 17 & 17,5 \\
\hline $\begin{array}{c}\text { Burning surface change } \\
(\%)\end{array}$ & 0 & 8 & 14 & 19 & 21 & 22 \\
\hline II phase [0,5(R2 - R1) $\leq$ Burnt layer thicknss $\leq D-0,5(R 2-R 1)]$ \\
\hline $\begin{array}{c}\text { Burnt layer thickness } \\
(\mathrm{mm})\end{array}$ & 17,6 & 22,5 & 32,5 & 42,5 & 47,5 & 50 \\
\hline $\begin{array}{c}\text { Burning surface change } \\
(\%)\end{array}$ & 1 & 3 & 10 & 18 & 22 & 24 \\
\hline III phase [D-0,5(R2 - R1) $\leq$ Burnt layer thickness $\leq R 4-R 3-D)]$ \\
\hline $\begin{array}{c}\text { Burnt layer thickness } \\
(\mathrm{mm})\end{array}$ & 50,1 & 55 & 60 & 65 & 69,5 & 70 \\
\hline Burning surface(\%) & 2 & 7 & 11 & 15 & 19 & 20 \\
\hline \hline
\end{tabular}

Fig. 2 shows that the combustion of this type propellant grain leads to large changes in the burning surface $(24 \%$ increase in relation to optimal value) with the burning time.

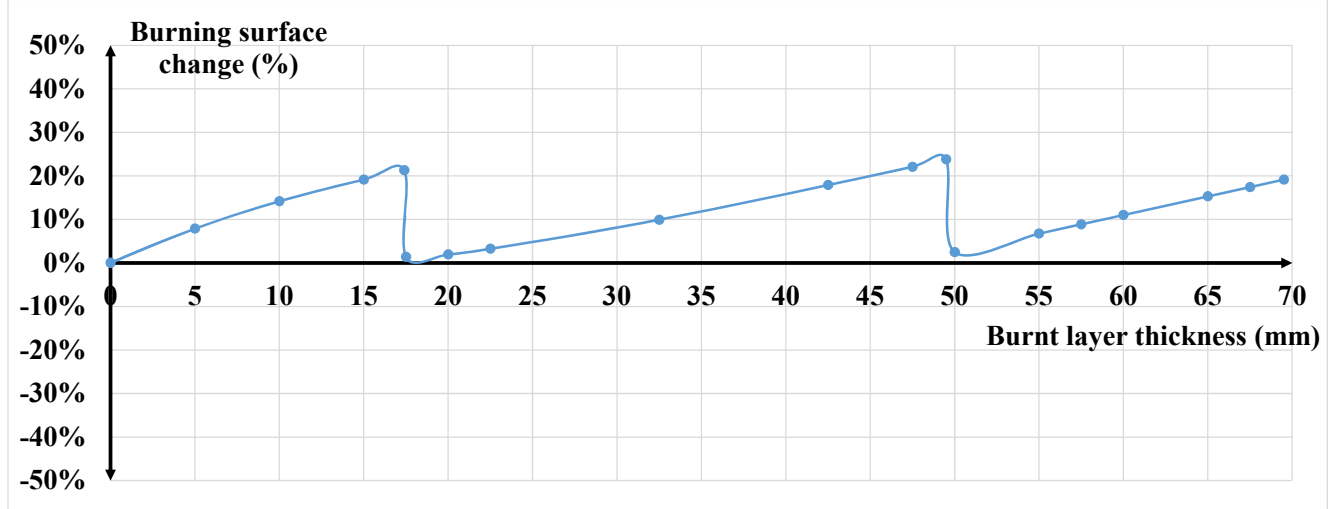

Figure 2. Burning surface change vs burnt layer thickness graph for Anchor type of grain

After the Anchor grain shape development of burning surface in the Creo program, a mathematical analysis of the burning surface was done.

In order to better define the mathematical model of the burning surface distribution, the combustion is divided into different phases.

Combustion of the Anchor propellant shape takes place in 3 characteristic phases:

\section{Phase I}

$0 \mathrm{~mm}<$ Burnt layer thickness $\leq 17,5 \mathrm{~mm}$ 

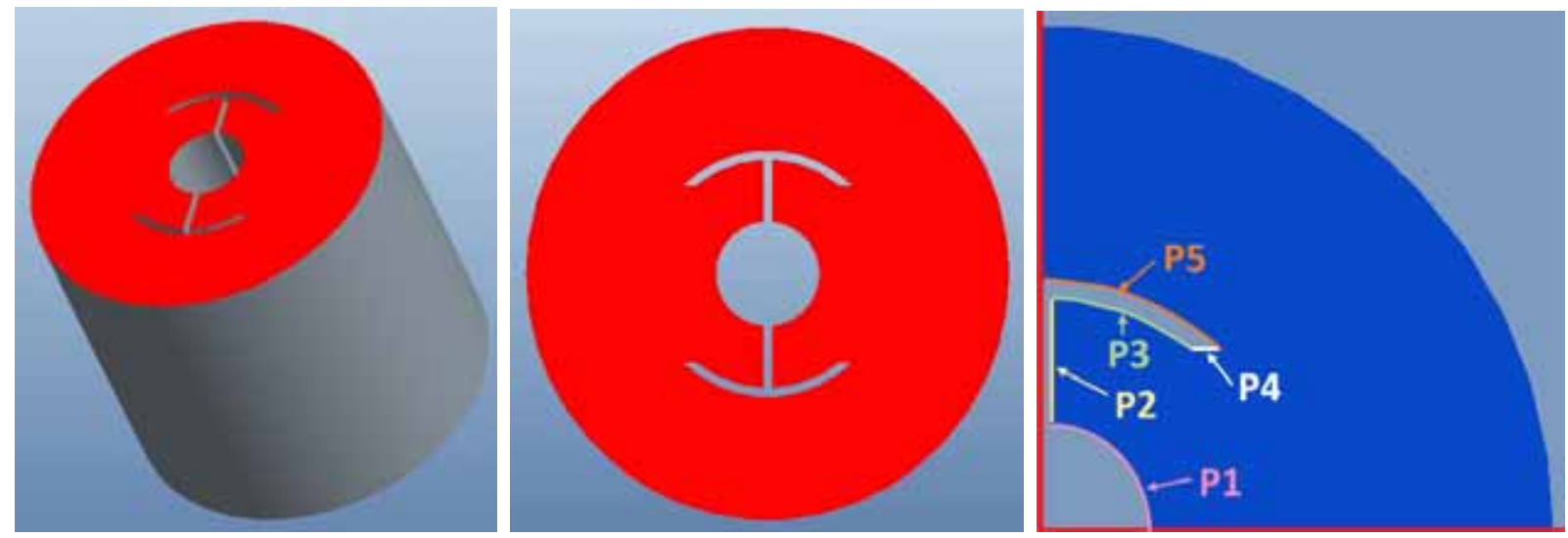

Figure 3. Appearance of the propellant grain at the start of the first phase of combustion with the dimensions on which the mathematical model of combustion is concerned

At each phase, the values of all individual parts of the perimeter have to be defined.

With equations from 1 to 8 , the burning surface in the first phase of combustion is mathematically defined. All the parameters of the given equations are shown in Fig.3.

In the phase one, the burnt layer thickness $(Y)$ is between the following limits:

$$
0 \leq Y \leq \frac{R 2-R 1}{2}
$$

Perimeter in the phase one $\left(P_{\mathrm{I}}\right)$ :

$$
P_{I}=4(P 1+P 2+P 3+P 4+P 5)
$$

Calculation for $P_{\mathrm{I}}$ :

$$
\begin{gathered}
P 1=(R 1+Y) a \cos \left(\frac{\frac{S}{2}+Y}{R 1+Y}\right) \\
P 2=(R 2-Y) \sin \left[a \cos \left(\frac{\frac{S}{2}+Y}{R 2-Y}\right)\right]- \\
-(R 1+Y) \sin \left[a \cos \left(\frac{\frac{S}{2}+Y}{R 1+Y}\right)\right]
\end{gathered}
$$

$$
\begin{gathered}
P 3=(R 2-Y)\left[\frac{\pi}{2}-a \sin \left(\frac{D-Y}{R 2-Y}\right)-a \sin \left(\frac{\frac{S}{2}+Y}{R 2-Y}\right)\right] \\
P 4=(R 3+Y) \cos \left[a \sin \left(\frac{D-Y}{R 3+Y}\right)\right]- \\
-(R 2-Y) \cos \left[a \sin \left(\frac{D-Y}{R 2-Y}\right)\right]
\end{gathered}
$$

$$
P 5=(R 3+Y)\left[\frac{\pi}{2}-a \sin \left(\frac{D-Y}{R 3+Y}\right)\right]
$$

Burn surface area $\left(A_{P}\right)$ in the phase one:

$$
A_{P}=P_{I}(L-n Y)(L=\text { length of grain, } n=0,1,2)
$$

$n=$ the number of burning foreheads, in this case $n=0$

Phase II

$17,5 \mathrm{~mm}<$ Burnt layer thickness $\leq 50 \mathrm{~mm}$
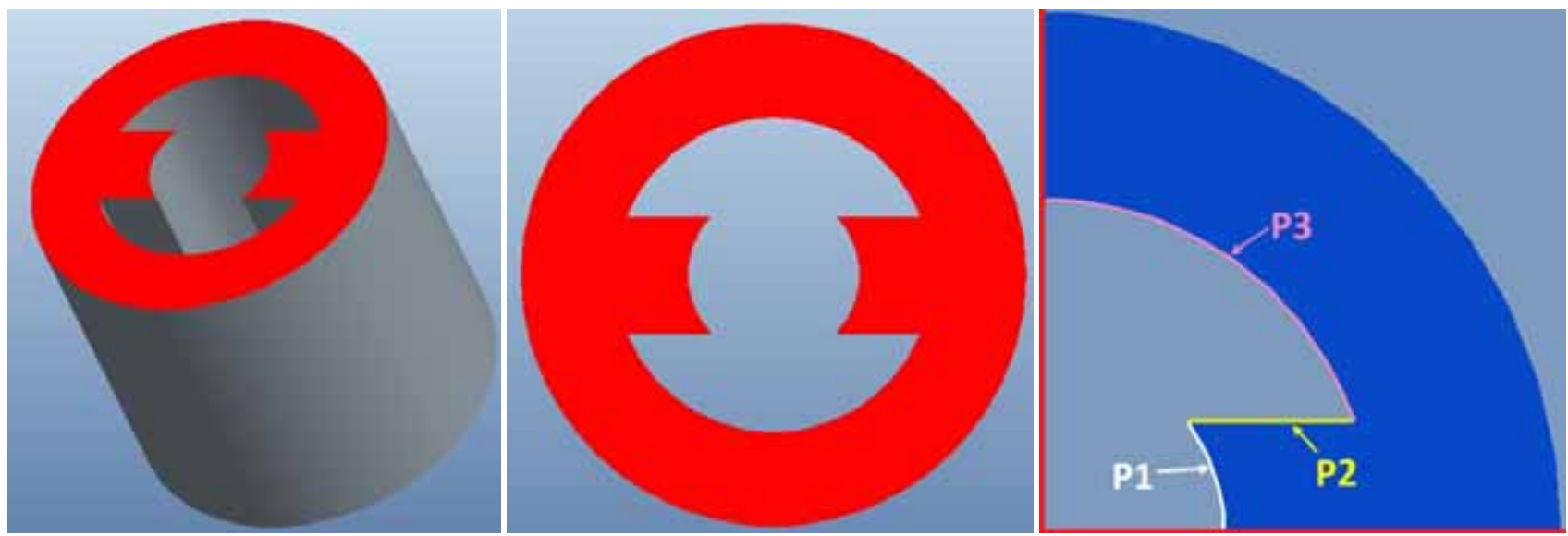

Figure 4. Appearance of the propellant grain at the start of the second phase of combustion with the dimensions on which the mathematical model of combustion is concerned 
With equations from 9 to 15 , the combustion surface in the second phase of combustion is mathematically defined. All the parameters of the given equations are shown in Fig.4.

In the phase two, burnt layer thickness, for the entire range of:

$$
\frac{R 2-R 1}{2} \leq Y \leq D^{I} ; D^{I}=D-\frac{(R 2-R 1)}{2}
$$

Perimeter in the phase two $\left(P_{I I}\right)$ :

$$
P_{I I}=4(P 1+P 2+P 3)
$$

Exponents of certain sizes (e.g $D^{I}, R 3^{I}, R 1^{I}$, etc.) represent the values of these sizes at the end of the previous combustion phase.

Calculation for $P_{I I}$

$$
P 1=\left(R 1^{I}+Y\right) a \sin \left(\frac{D^{I}-Y}{R 1^{I}+Y}\right)
$$

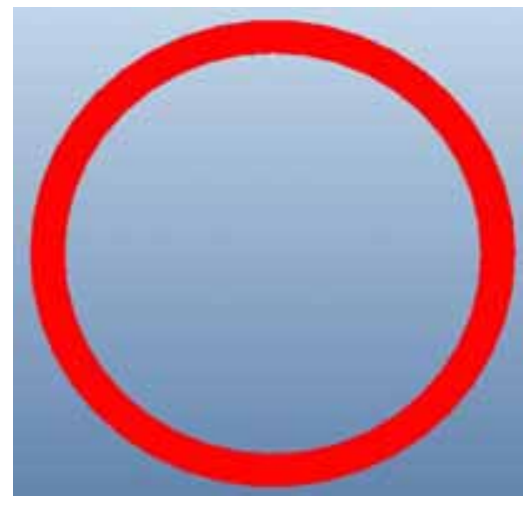

Burn surface area in the phase two:

$$
A_{P}=P_{I I}(L-n Y)
$$

\section{Phase III}

$50 \mathrm{~mm}<$ Burnt layer thickness $\leq 70 \mathrm{~mm}$

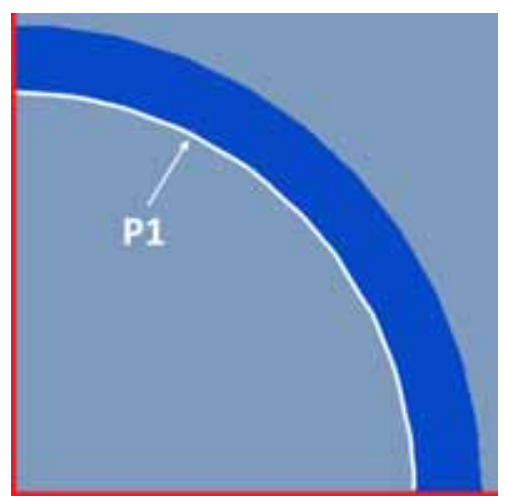

Figure 5. Appearance of the propellant grain at the start of the third phase of combustion with the dimensions on which the mathematical model of combustion is concerned

With equations from 16 to 20 , the combustion surface in the third phase of combustion is mathematically defined. All the parameters of the given equations are shown in Fig.5.

In the phase three, burnt layer thickness, for the entire range of:

$$
D-\frac{(R 2-R 1)}{2} \leq Y \leq(R 4-R 3-D)
$$

Perimeter in the phase three $\left(P_{I I I}\right)$ :

$$
P_{I I I}=4(P 1+P 2+P 3+P 4+P 5)
$$

Calculation for $P_{I I I}$

$$
P 3=\left(R 3^{I I}+Y\right) \frac{\pi}{2}
$$

$$
R 3^{I I}=R 3^{I}+D-\frac{(R 2-R 1)}{2}
$$

Burn surface area in the phase three:

$$
A_{P}=P_{I I I}(L-n Y)
$$

The resulting mathematical model of combustion was used to obtain graph burning surface change-burnt layer thickness, Fig.6, which was constructed by changing the burnt layer thickness from 0 to $70 \mathrm{~mm}$ (web increment: $1 \mathrm{~mm}$ ) and obtaining burning surface values.

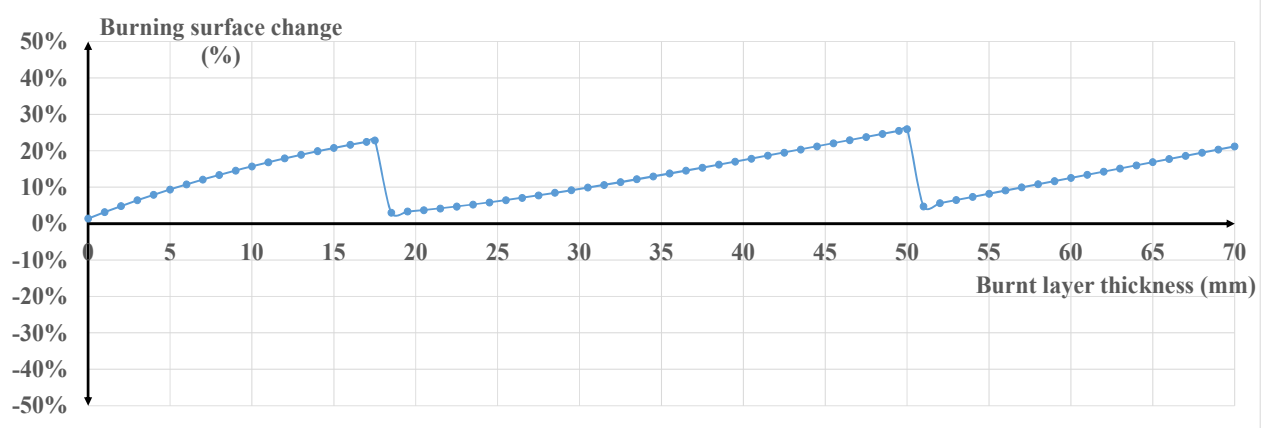

Figure 6. Changes of the burning surface values with the burnt layer thickness for optimized shape of Anchor, based on the mathematical model 
The combustion process of this propellant form is shown in the three-dimensional models in Fig.7, obtained in the Creo

program.

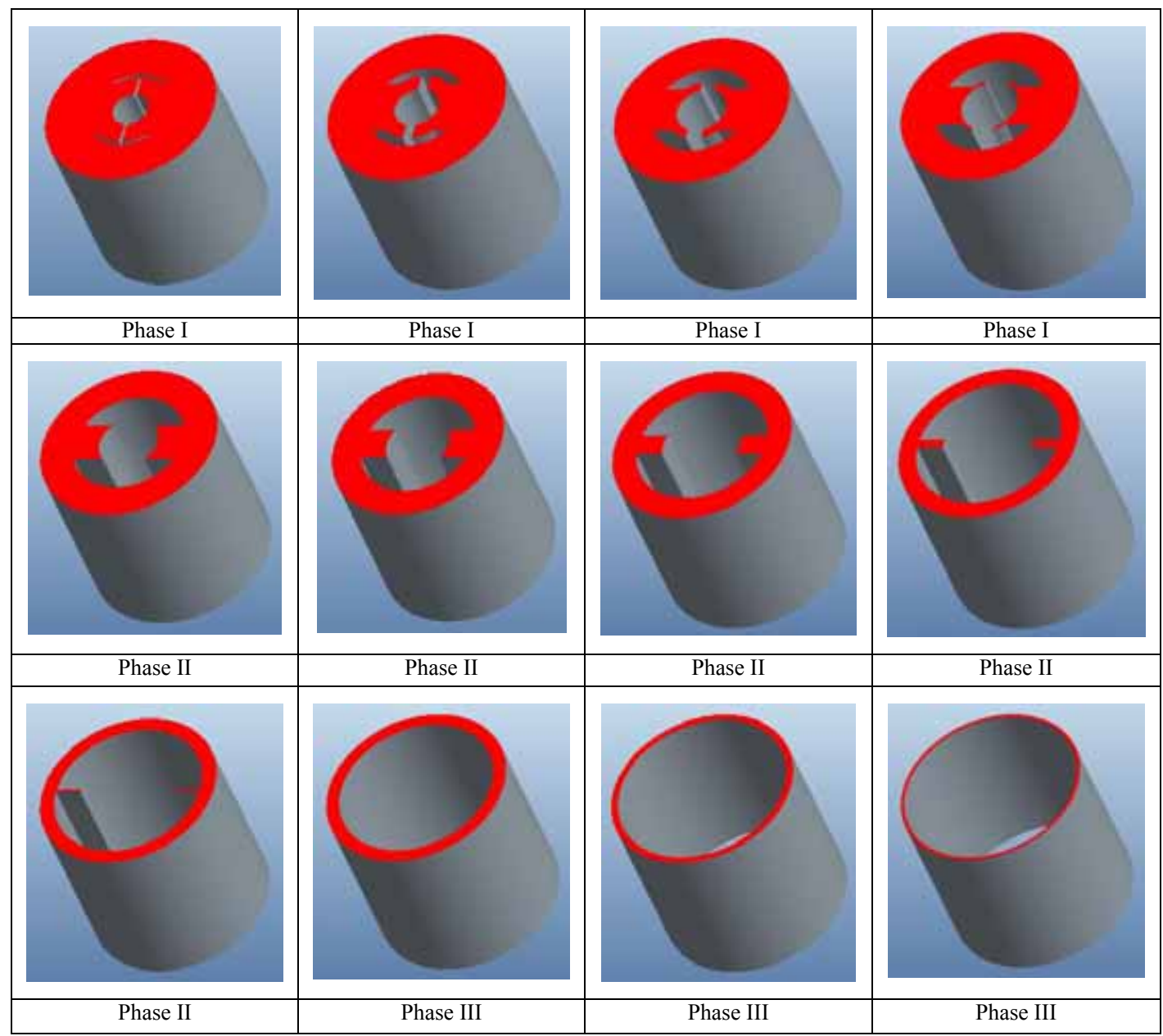

Figure 7. Three-dimensional view of characteristic the Anchor propellant shapes at different time combustion moments

The obtained burning surface values using the Creo software and the classical formulas in the closed form are given in Table 2.

Table 2. The burning surface values in relation to changing the burnt layer thickness for Anchor shape propellant

\begin{tabular}{|c|c|c|c|c|c|c|c|c|c|c|c|c|}
\hline \multirow{2}{*}{$\begin{array}{l}\text { Burnt layer thickness } \\
\qquad(\mathrm{mm})\end{array}$} & \multicolumn{4}{|c|}{ Phase I } & \multicolumn{4}{|c|}{ Phase II } & \multicolumn{4}{|c|}{ Phase III } \\
\hline & 0 & 5 & 10 & 15 & 20 & 32,5 & 42,5 & 49,5 & 50 & 55 & 60 & 65 \\
\hline $\begin{array}{c}\text { Anchor shape based on } \\
\text { Creo programe } \\
\left(\mathrm{mm}^{2}\right)\end{array}$ & 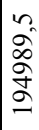 & 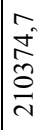 & 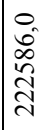 & $\begin{array}{l}n \\
0 \\
\tilde{n} \\
\tilde{n} \\
\tilde{n}\end{array}$ & $\begin{array}{l}0 \\
\hat{a} \\
\infty \\
\infty \\
\infty \\
-1\end{array}$ & $\begin{array}{l}\infty \\
\stackrel{\infty}{\infty} \\
\stackrel{+}{\sim} \\
\stackrel{\sim}{v}\end{array}$ & 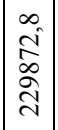 & $\begin{array}{l}\vec{n} \\
\stackrel{m}{\vec{d}}\end{array}$ & $\begin{array}{l}1 \\
2 \\
\infty \\
\infty \\
2\end{array}$ & 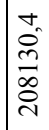 & 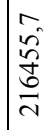 & 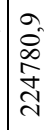 \\
\hline $\begin{array}{l}\text { Anchor shape based on } \\
\text { mathematical model of } \\
\text { combustion } \\
\left(\mathrm{mm}^{2}\right)\end{array}$ & $\begin{array}{l}m \\
\alpha \\
\infty \\
\alpha \\
\dot{\alpha}\end{array}$ & 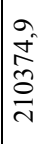 & 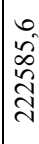 & 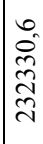 & $\begin{array}{l}- \\
\infty \\
N \\
\infty \\
\infty\end{array}$ & $\begin{array}{l}\infty \\
\dot{\infty} \\
\stackrel{+}{ \pm} \\
\stackrel{\sim}{v}\end{array}$ & 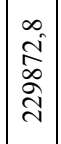 & $\underset{\substack{n \\
\stackrel{m}{m}}}{\stackrel{\sim}{\sim}}$ & $\begin{array}{l}2 \\
2 \\
2 \\
\infty \\
2 \\
2\end{array}$ & $\begin{array}{l}n \\
0 \\
\tilde{n} \\
\infty \\
\infty \\
0\end{array}$ & $\begin{array}{l}n \\
i n \\
\tilde{\sigma} \\
\end{array}$ & 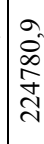 \\
\hline
\end{tabular}

Also, in terms of the mean values, the obtained results of burning surface of the Anchor shape based on Creo programe and based on classical formulas in the closed form are consistent, Table 2.

This means that the execution of mathematical formulas of combustion the Anchor shape in closed form was carried out in an appropriate manner.

The dimensions of the Anchor shape propellant are shown in Table 3.

Table 3. Dimensions of the Anchor shape propellant

\begin{tabular}{|c|c|c||}
\hline Representation & Values & Units \\
\hline \hline R4 & $0,5 \mathrm{C}^{*}$ & $\mathrm{~mm}$ \\
\hline R3 & $0,25 \cdot \mathrm{C}$ & $\mathrm{mm}$ \\
\hline R2 & $0,2321 \cdot \mathrm{C}$ & $\mathrm{mm}$ \\
\hline R1 & $0,1071 \cdot \mathrm{C}$ & $\mathrm{mm}$ \\
\hline $\mathrm{D}$ & $0,1786 \mathrm{C}$ & $\mathrm{mm}$ \\
\hline $\mathrm{S}$ & $0,0179 \cdot \mathrm{C}$ & $\mathrm{mm}$ \\
\hline $\mathrm{L}$ & $0,946 \cdot \mathrm{C}$ & $\mathrm{mm}$ \\
\hline
\end{tabular}

* The outer diameter of the Anchor grain propellant

Obtained burning surface values for each web increment by using mathematical formulas are compared with PTC Creo solution of Anchor grain shape and can be seen from Fig.8. 


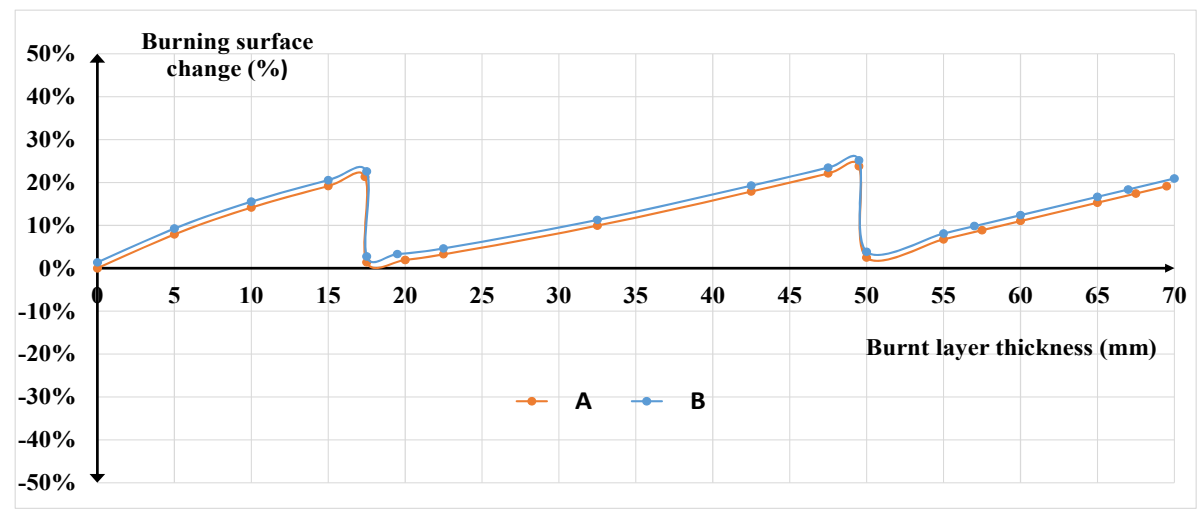

Figure 8. Changes of the burning surface values vs burnt layer thickness graphs for Anchor type of grain: A - created by using results from the Creo software, B created by using a mathematical model of combustion

The obtained results show the good agreement of the software solution with the obtained mathematical model of combustion (Figure 8), which means that the mathematical description of the combustion process of this propellant type was carried out in an appropriate way, respectively.

Furthermore, the significant correlation between software solution and mathematical model with formulas in closed form, which is 0,99975 , confirms that using the PTC Creo software is an appropriate solution for purpose of numerical design of a solid propellant grain with such a complex shape that it is not possible to develop a mathematical model in closed form.

\section{Conclusion}

The grain burnback analysis is the one of the most important steps of solid rocket motor design.

In this paper, the increment method is used by PTC Creo software solution to estimate burning surface. The results were compared with the results obtained by classical formulas in the closed form.

An example of the Anchor shaped grain channel has been considered using the PTC Creo software solution, in order to determine the burning surface dependence on burned depth. The obtained results have shown the good agreement of the software solution with the results obtained by classical mathematical model.

The obtained matching results indicate that the selected numerical calculation method can be applied to any complex propellant grain form for which it is not possible to construct the classical formulas for the development of a burning surface in the closed form.

The results obtained show that various grain design requirements can be met using the proposed Creo programe for the grain design process.

\section{Literature}

[1] SIVA,V.: Investigation of Solid Propellant Rocket Engine - An Theoretical Approach, Journal of Engineering Research and Application, ISSN: 2248-9622, 2017, Vol.7, No.9, (Part -5), pp.73-75.

[2] Solid propellant grain design and internal ballistics, NASA Space Vehicle Design Criteria (Chemical Propulsion), SP-8076, 1972.
[3] SAVKOVIĆ,M.: Optimizacija unutrašnjebalističkih karakteristika raketnog motora sa čvrstom pogonskom materijom, Doktorska disertacija, Faculty of Mechanical Engineering, Belgrade, SERBIA, 1995.

[4] REDDY,K,O.: Burnback Analysis of 3-D Star Grain Solid Propellant, International Journal of Advanced Trends in Computer Science and Engineering, 2013, Vol.2, No.1, pp.215-223.

[5] JOHANNSSON,M.: Optimization of Solid Rocket Grain Geometries, MSc Thesis, Stockholm, Sweden, 2012.

[6] TRAVIS,S.T.: Introduction to Rocket Science an Engineering, 2009, CRC Press, ISBN-13: 978-1-4200-7529-8,

[7] HAINLINE,R.CLAY: Design optimization of solid rocket motor grains for internal ballistic performance, MSc Thesis, College of Engineering and Computer Science at the University of Central Florida, 2006.

[8] SUTTON,G.P.: Rocket Propulsion Elements, 7th ed., John Wiley and Sons, Inc., New York, 2001.

[9] MARJANOVIĆ,G.: Program SVOD for Solid Propellant Grain Design, 5th International Scientific Conference on Defensive Technologies OTEH 2012, 18-19 September 2012, Belgrade, SERBIA, ISBN 978-86-81123-58-4, pp.355-360.

[10] PÜSKÜLCÜ,G., ULAS,A.: 3-D grain burnback analysis of solid propellant rocket motors: Part 2 - modeling and simulations, Aerospace Science and Technology, 2008, Vol.12, pp.585-591.

[11] WANDO,K., TAEHO,K., SANGMIN,K.A, WOONGSUP,Y.: $3 D$ grain burnback analysis using the partial interface tracking method, Aerospace Science and Technology, 2017, Vol.68,pp.58-67.

[12] PATAN,S., SANTOSH KUMAR,Y.N.V., NAZUMUDDIN,SK.: Design and Geometrical Analysis of Propellant Grain Configurations of a Solid Rocket Motor, ISSN: 2321-9939, 2014, Vol.2, No.4, pp.3417-3427.

[13] DONG-HUI,W.: An integrated framework for solid rocket motor grain design optimization, J Aerospace Engineering, 2014, Vol.228, No.7, pp.1156-1170.

[14] RIDER,J.M.: Designing with Creo Parametric 4.0, SDC pulications, USA, ISBN-13: 978-1-63057-102-3, 2017.

[15] YUSUF,A.: Numerical burnback analysis of three dimensional solid propellant grains, Middle East technical university, Master thesis, Ankara, Turkey, 2015.

[16] PÜSKÜLCÜ,G.: Analysis of 3-D Grain Burnback of Solid Propellant Rocket Motors and Verification with Rocket Motor Tests, MSc Thesis, Dept. of Mechanical Engineering, METU, 2004. 


\title{
Numerički metod dizajna pogonskog punjenja sa čvrstim gorivom
}

\author{
U ovom radu izvršena je analiza razvoja sagorevanja raketnog zrna oblika sidro za raketni motor sa čvrstim gorivom. Proces \\ dizajna uključuje parametarsko modelovanje geometrije u PTC Creo softveru kroz dinamičke varijable koje definišu ovu \\ složenu konfiguraciju. \\ Analiza razvoja sagorevanja zrna se opisuje nastajanjem novih površina na određenim koracima sagorelog sloja $i$ \\ izračunavanjem geometrijskih karakteristika za svaki inkrement veba. \\ Površine sagorevanja zrna se određuju pomoću PTC Creo-a, verzija 4.0, korišćenjem zadatog koraka na svakih 5 mm \\ debljine sagorelog sloja. Ovaj postupak daje veličine preostalih površina raketnog zrna tokom procesa sagorevanja u \\ raketnom motoru. \\ Numerički rezultati dobijeni korišćenjem PTC Creo programa su poređeni sa izračunatim površinama sagorevanja pomoću \\ izvedenih formula u zatvorenoj formi koje opisuju ovu geometriju zrna, čime je proveravana ispravnost numeričke metode \\ proračuna. \\ Prikazani rad se bavi primenom softverskog alata PTC Creo za dizajn bilo kojeg proizvoljnog oblika čvrstog pogonskog \\ punjenja raketnog motora. Ovaj rad je koncentrisan na numeričkom opisu promene površine tokom procesa sagorevanja $i$ \\ određivanju matematičkog modela procesa sagorevanja.
}

Ključne reči: raketni motor, pogonsko punjenje, raketno gorivo, čvrsto raketno gorivo, geometrijski oblik, sagorevanje, površina sagorevanja, modelovanje, numeričke metode.

\section{Численный метод расчёта заправки привода твёрдым топливом}

В данной статье был проведён анализ разработки сгорания ракетного якорного двигателя для ракетного двигателя с твёрдым топливом. Процесс проектирования включает параметрическое моделирование геометрии в программном обеспечении РТC Сrео с помощью динамических переменных, которые определяют эту сложную конфигурацию. Анализ развития сгорания зерна описывается формированием новых поверхностей на определённых ступенях горящего слоя и вычислением геометрических характеристик для каждого приращения полотна.

Области сгорания зерна определяются с помощью РТС Сrео, версия 4.0, с использованием данного шага на каждые 5 мм толщины горящего слоя. Эта процедура даёт размер оставшейся поверхности зерна ракеты во время процесса сгорания в ракетном двигателе.

Численные результаты, полученные с использованием программы PTC Creo, сравниваются с вычисленными поверхностями сгорания с использованием замкнутых уравнений замкнутой формы, описывающих эту геометрию зерна, что подтверждает правильность метода численных расчётов.

Настоящая статья посвящена применению программного инструмента РTC Creо для проектирования любой произвольной формы заряда твёрдым топливом ракетного двигателя. Эта работа сосредоточена на численном описании изменения поверхности в процессе сгорания и на определении математической модели процесса сгорания.

Ключевые слова: ракетный двигатель, заправка привода, ракетное топливо, твёрдое ракетное топливо, геометрическая форма, сгорание, поверхность сгорания, моделирование, численные методы.

\section{Méthode numérique du dessin pour la charge propulsive à propergol solide}

Dans ce travail on a fait une analyse du développement de la combustion du grain de fusée en forme d'ancre pour le moteur de fusée à propergol solide. Le processus du dessin inclut la modélisation paramétrique de la géométrie dans le logiciel PTC Creo par les variables qui définissent cette complexe configuration. L'analyse du développement de grain est décrite par la création de nouvelles surfaces sur les pas définis de la couche brûlée et par le calcul des caractéristiques géométriques pour chaque incrément de web. Les surfaces du grain brûlé sont définies par le logiciel PTC Creo,version 4.0, en utilisant le pas déterminé pour chaque $5 \mathrm{~mm}$ d'épaisseur de cette couche. Ce procédé donne les tailles des surfaces restées du grain pendant le processus de combustion dans le moteur à fusée. Les résultats numériques obtenus par le programme PTC Creo ont été comparés avec les surfaces calculées de la combustion à l'aide des formules en forme fermée qui décrivent cette géométrie de grain et de cette manière on a vérifié l'exactitude de la méthode numérique de calcul. Le travail présenté s'occupe de l'application du logiciel PTC Creo pour le dessin de n'importe quelle forme du propergol solide du moteur à fusée. Ce travail est centré sur la description numérique de la surface pendant le processus de combustion ainsi que sur la détermination du modèle numérique de ce processus.

Mots clés: moteur à fusée, charge propulsive, propergol, propergol solide, forme géométrique, combustion, surface de combustion, modélisation, méthodes numériques. 